\title{
Microstructure and brittle fracture resistance of layered steel composites produced by explosion welding and pack rolling followed by heat treatment
}

\author{
S. V. Kuteneva ${ }^{\dagger, 1}$, S. V. Gladkovsky ${ }^{1}$, D. A. Dvoynikov ${ }^{1}$, S. N. Sergeev ${ }^{2}$ \\ †esv@imach.uran.ru \\ ${ }^{1}$ Institute of Engineering Science, UB RAS, 34 Komsomolskaya St., Yekaterinburg, 620049, Russia \\ ${ }^{2}$ Institute for Metals Superplasticity Problems RAS, 39 S. Khalturin St., Ufa, 450001, Russia
}

In the present paper, the microstructure and fracture resistance characteristics of 7-layered composites based on Fe-2Mn-1Si low carbon low alloyed steel and Fe-11Cr-9Ni-2Mo-1Ti maraging steel obtained by two different methods such as explosion welding and hot pack rolling with subsequent heat treatment were investigated. It was shown that an important microstructural features of Fe-2Mn-1Si steel layers are associated with the formation of a fragmentation zone $\sim 10 \mu \mathrm{m}$ wide with a size of structural elements 0.5-1.0 $\mu \mathrm{m}$ near the interface in the welded composites and the appearance of decarburized ferrite zone $\sim 50 \mu \mathrm{m}$ wide in the hot-rolled composites. According to local energy dispersive X-ray microanalysis, at the interface of welded and hot-rolled composites, the most active diffusion processes near of Fe-2Mn-1Si and Fe-11Cr-9Ni-2Mo-1Ti steel interlayer borders occur during the composites production by pack rolling. It was established that explosion welding makes it possible to retain the initial microstructure of steel blanks, with the exception of a narrow near-weld zone of grain fragmentation. After the subsequent heat treatment of explosively welded and hot-rolled composites, Fe-2Mn-1Si steel layers are characterized by a viscous ferrite(sorbitol)-pearlite microstructure, and Fe-11Cr-9Ni-2Mo-1Ti steel layers possess a martensitic microstructure with strengthening intermetallic particles. From the results of impact tests at temperatures from $+20^{\circ} \mathrm{C}$ to $-60^{\circ} \mathrm{C}$, it was found that the impact strength KCV and energy of impact loading $A$ of the hot-rolled composites are 2 and $3.5-5.4$ times higher than the ones of the welded composites, respectively.

Keywords: layered composite, explosion welding, pack rolling, low carbon steels, microstructure.

\section{Introduction}

Currently, layered metallic composites (LMC) are related to promising materials for the manufacture of machine parts and structural elements working in cold climates. They are increasingly used in such areas as aerospace, nuclear industry, shipbuilding and automotive [1-3]. High strength of LMC is achieved by using steels with an increased ultimate tensile strength and yield strength as one of the composite components, such as maraging steel [4-6]. In [7-9], the authors showed the efficiency of using maraging steel in the composition of steel/steel and steel/aluminum layered materials obtained by explosion welding technology. However, the microstructure and mechanical properties of the LCM produced by pack rolling and containing layers of high-strength maraging steel remain insufficiently explored. At the same time, the substantiation of the choice of technology for manufacturing layered composites requires comparative studies of the microstructure and the complex of mechanical properties of similar composites obtained by explosion welding and pack rolling.

The aim of this study was to research structural features of the interface, the distribution chemical elements on the interlayer borders, the microstructure of the layers, and the fracture resistance characteristics of 7-layered composites fabricated by high-energy (explosion welding) and deformation (pack rolling) methods.

\section{Materials and methods}

The objects of this study are 7-layered composites on base of Fe-2Mn-1Si low carbon steel and Fe-11Cr-9Ni-2Mo-1Ti maraging steel, obtained by alternative technologies of explosion welding and pack rolling. The chemical composition of the steels was determined using a SPECTROMAXx device. The Fe-2Mn-1Si low carbon steel has the following chemical composition (wt.\%): $0.12 \mathrm{C}, 0.68 \mathrm{Si}, 1.32 \mathrm{Mn}, 0.07 \mathrm{Cr}, 0.07 \mathrm{Ni}$, $0.01 \mathrm{Mo}, 0.04 \mathrm{Al}, 0.12 \mathrm{Cu}, 0.01 \mathrm{~S}, 0.02 \mathrm{P}$ and balance Fe. The chemical composition of Fe-11Cr-9Ni-2Mo-1Ti maraging steel (wt.\%): $0.02 \mathrm{C}, 0.16 \mathrm{Si}, 0.08 \mathrm{Mn}, 10.65 \mathrm{Cr}$, 9.35 Ni, 1.97 Mo, 0.09 Al, 0.9 Ti, 0.09 Nb, 0.1 Cu, 0.004 S, $0.004 \mathrm{P}$ and balance Fe. The total volume content of the Fe-11Cr-9Ni-2Mo-1Ti high-strength steel in layered composites is equal to $25 \%$. In multilayer packages, Fe-2Mn-1Si sheet steel with a thickness of $2 \mathrm{~mm}$ was in the initial normalized state. Layers of Fe-11Cr-9Ni-2Mo-1Ti steel with a thickness of $1 \mathrm{~mm}$ in the layered package before the pack rolling were in the quenched state, and in the layered package before the explosion welding - after the combined deformation processing for creating of ultrafine-grained (UFG) structure, which was carried out at the Institute for Metals Superplasticity Problems, Russian Academy of Sciences (Ufa) using a combined deformational process, as described in [10]. 
The explosion welding of 7-layered composites was carried out in two stages at the Lavrentyev Institute of Hydrodynamics Siberian Branch, Russian Academy of Sciences (Novosibirsk) with the assistance of Cand. of Phys-Math. Sci. V. I. Mali. The explosion welding technology adapted for the fabrication of layered composites on the base of the studied materials (a combination of low-carbon and high-strength maraging steels) was described in [11]. The pack rolling of 7-layered composites was performed at a temperature of $1050^{\circ} \mathrm{C}$ with a total reduction of $42 \%$ using a duo rolling mill at the CSC "Plastometriya" of the Institute of Engineering Science, Ural Branch, Russian Academy of Sciences (Yekaterinburg). The composites obtained by hot pack rolling were cooled in air to room temperature, and then subjected to quenching in water from a temperature of $920^{\circ} \mathrm{C}$. Heat treatment of welded and hot-rolled composites was performed at a temperature of $500^{\circ} \mathrm{C}$ with holding for 3 hours to regulate the mechanical properties of the layers. This heart treatment corresponded to the strengthening aging for the Fe-11Cr-9Ni-2Mo-1Ti steel and to the high-tempering regime for the Fe-2Mn-1Si steel.

The interface structure and microstructure of the layers of the obtained LMC were studied using a Neophot-21 optical microscope (OM) and Tescan Vega II XMU and Tescan Mira 3 LMH scanning electron microscopes (SEM) in the mode of secondary, reflected electrons, and orientational phase contrast. Local energy dispersive X-ray (EDX) microanalysis was performed by means of a Tescan Vega II XMU SEM with an INCA Energy 450XT integrated energy dispersive attachment permitting to estimate the distribution of chemical elements at the interfaces of the composites. From the results of Charpy $\mathrm{V}$-notch impact tests at temperatures of +20 and $-60^{\circ} \mathrm{C}$, the brittle fracture resistance characteristics of the 7-layered steel/steel composites were determined using a Tinius Olsen IT542M instrumented pendulum impact test machine. The impact samples of composites were made of type $11(10 \times 10 \times 55 \mathrm{~mm})$ in accordance with the requirements of the Russian standard GOST 9454 with a $\mathrm{V}$-notch oriented across the layers (crack-arrester type) [12]. The separation of the energy of crack initiation $\left(A_{i}\right)$ from the total energy of impact loading $(A)$ was performed according to GOST 22848-77 on the base of the analysis of experimental diagrams recorded during impact loading.

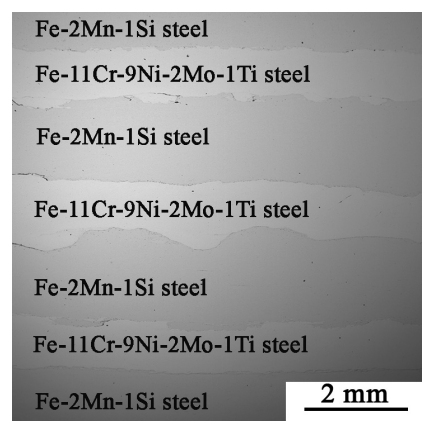

a

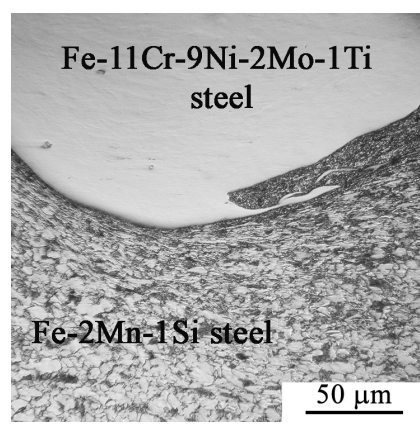

b

\section{Results and discussion}

According to the results of the structural study of the 7-layered explosively welded composite, wavy and flat shapes of the interface formed during the explosive effect were identified (Fig. 1a,b). Welding defects in the form of pores, cracks or inclusions were absent at the explosively welded joints of the composites. From the EDX measurements, it was determined that a narrow diffusion zone $(5-7 \mu \mathrm{m})$ was formed in the interface of layers of the Fe-2Mn-1Si steel and the Fe-11Cr-9Ni-2Mo-1Ti steel, the width of which does not change during the subsequent heat treatment. The hot-rolled 7-layered composites are characterized by a flat interface (Fig. 1c, d). Elongated inclusions of oxide and carbide particles at the interface of hot-rolled composites have a complex chemical composition containing alloying elements of adjacent layers (Mn, Si, Cr, Ti). These particles coagulate as a result of the active development of diffusion processes during hot pack rolling. In this case, the diffusion zone at the interface reaches up to $\sim 25 \mu \mathrm{m}$. Subsequent heat treatment of hot-rolled composites did not contribute to a noticeable expansion of the diffusion zone. A similar diffusion of chemical elements at the boundary of hot-rolled steel composites were noted in [13-14].

A microstructural analysis of the constituent layers of the welded composites showed that the initial ferrite-pearlite structure of the Fe-2Mn-1Si steel is preserved in the central part of these layers with an average grain size of ferrite of $\sim 12 \mu \mathrm{m}$ (Fig. $2 \mathrm{a}$ ). A fragmentation zone with a dynamically recrystallized structure up to $10 \mu \mathrm{m}$ wide with a size of structural elements $0.5-1.0 \mu \mathrm{m}$ is formed near interface on the side of the Fe-2Mn-1Si steel layer during explosively loading (Fig. 2 b).

The initial homogeneous UFG structure of the Fe-11Cr-9Ni-2Mo-1Ti steel with a size of microstructural elements of $50-200 \mathrm{~nm}$ is retained in the explosively welded composites (Fig. 2b,d). No significant difference in the microstructure of maraging steel were observed after the explosive effect. The softening of the Fe-2Mn-1Si steel layers occurs during heating of explosively welded composites at a temperature of $500^{\circ} \mathrm{C}$ for 3 hours. The reason of this is related to a decrease in the number of crystal defects and coagulation of the carbide phase in the Fe-2Mn-1Si steel. The layers of maraging steel are strengthened at a temperature of $500^{\circ} \mathrm{C}$ for 3 hours by segregating of $\mathrm{Fe}_{2}(\mathrm{Ti}, \mathrm{Mo})$ and $\mathrm{Ni}_{3} \mathrm{~T}$ intermetallic particles in martensite structure [15].
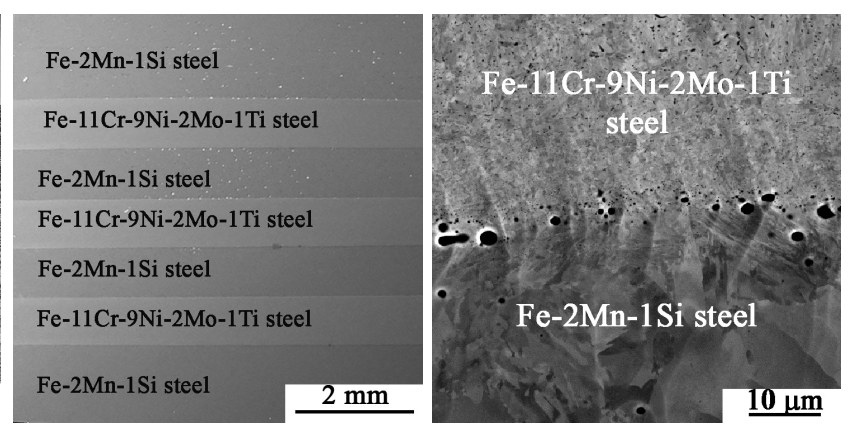

C d

Fig. 1. Images of interfaces of 7-layered explosively welded (a,b) and hot-rolled (c, d) composites. 
After hot pack rolling and air cooling of the 7-layered composites, the Fe-2Mn-1Si steel layers have a ferritic-pearlite microstructure with an average ferrite grain size of $\sim 12 \mu \mathrm{m}$ (Fig. 3 a). Due to the static recrystallization after hot rolling, the shape of ferritic grains becomes close to polygonal. A ferrite zone with a reduced amount of perlite near the interface on the side of the Fe-2Mn-1Si steel layers is found (Fig. $3 \mathrm{~b}$ ). The formation of a decarburized zone up to $50 \mu \mathrm{m}$ wide is the result of the ascending diffusion of carbon from low carbon to maraging steel layers. The microstructure of maraging steel layers as part of the composites after hot pack rolling is represented by a massive martensite (Fig. $3 \mathrm{c}$ ). The size of the martensitic laths varies from $20 \mu \mathrm{m}$ in the central part of the layer to $10 \mu \mathrm{m}$ at the interface of the layers. According to [15-16], the microstructure of the aged Fe-11Cr-9Ni-2Mo-1Ti steel contains no more than $10 \%$ residual austenite, which is not detected by optical microscopy.

A mixed troostite-ferritic structure is formed in the central part of the Fe-2Mn-1Si steel layers and a ferritic structure near the interface on the side of the mentioned steel (Fig. $4 \mathrm{a}$ ) with an average grain size of $\sim 12 \mu \mathrm{m}$ as result of hot-rolled composites quenching at a temperature of $920^{\circ} \mathrm{C}$. The width of the decarbonized zone in the Fe-2Mn-1Si steel layers of the hot-rolled composite reaches $100 \mu \mathrm{m}$ due to the continuing diffusion migration of carbon into the $\mathrm{Fe}-11 \mathrm{Cr}-9 \mathrm{Ni}-2 \mathrm{Mo}-1 \mathrm{Ti}$ steel layers at a temperature of $920^{\circ} \mathrm{C}$ (Fig. $4 \mathrm{~b}$ ). The microstructure of the $\mathrm{Fe}-11 \mathrm{Cr}-9 \mathrm{Ni}-2 \mathrm{Mo}-1 \mathrm{Ti}$ steel layers of the hot-rolled composites quenched at $920^{\circ} \mathrm{C}$ (Fig. 4 c) is like the microstructure of $\mathrm{Fe}-11 \mathrm{Cr}-9 \mathrm{Ni}-2 \mathrm{Mo}-1 \mathrm{Ti}$ steel layers of the explosively welding composites.

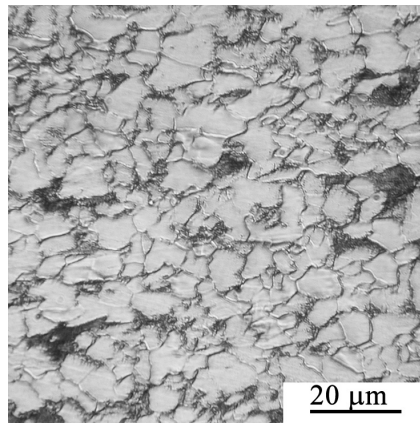

a

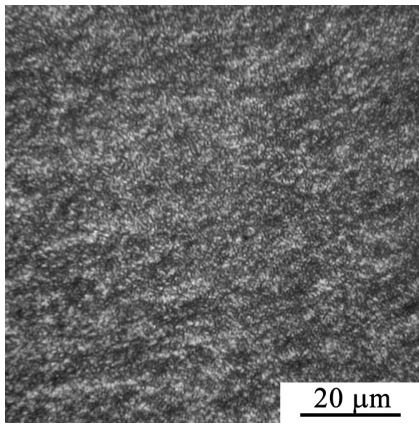

$\mathrm{b}$

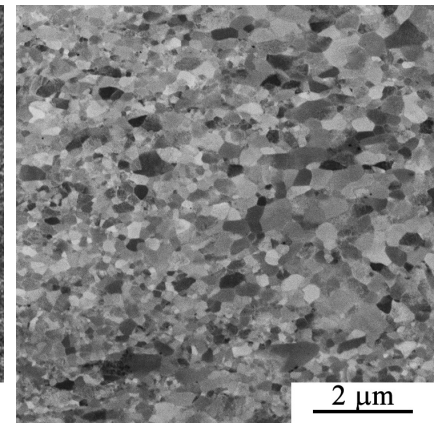

C

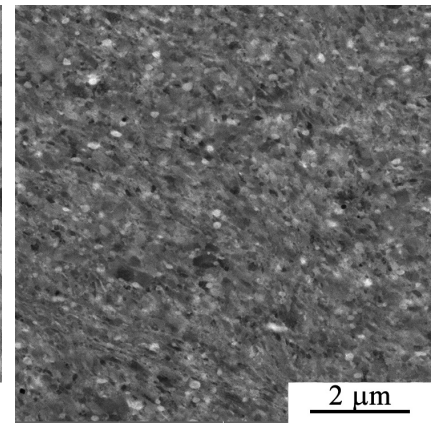

d

Fig. 2. The microstructure of composite components outside welding bonding (a,b) and at a distance of $5 \mu \mathrm{m}$ from the interface (c,d): Fe-2Mn-1Si steel (a,c) and Fe-11Cr-9Ni-2Mo-1Ti steel (b, d) layers before heat treatment.

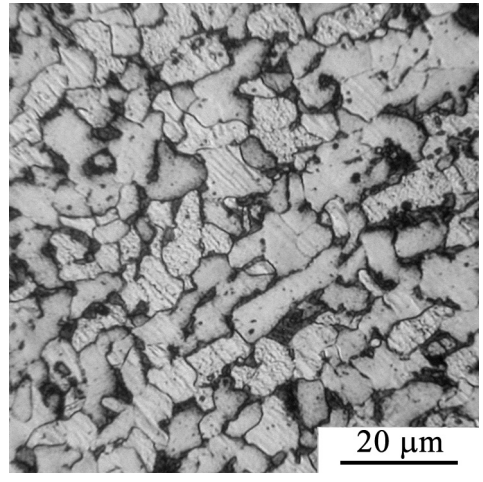

a

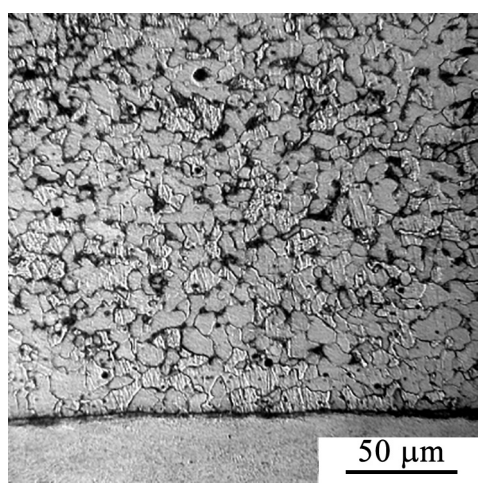

b

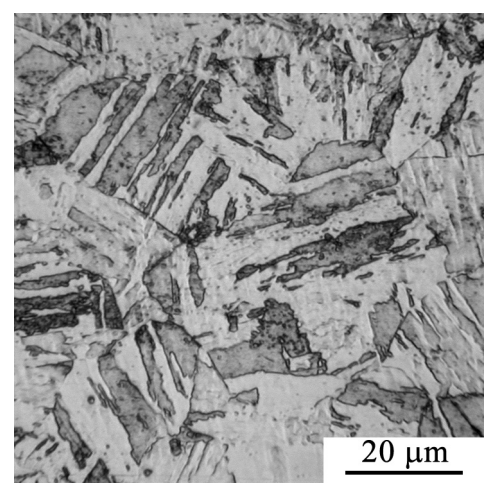

c

Fig. 3. The microstructure of the Fe-2Mn-1Si steel layers in the central part (a), at the interface (b) and the Fe-11Cr-9Ni-2Mo-1Ti steel layers in the central part (c) in the 7-layered hot-rolled composites before heat treatment.

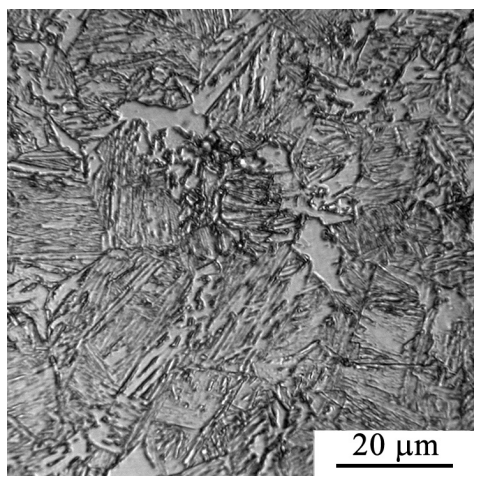

a

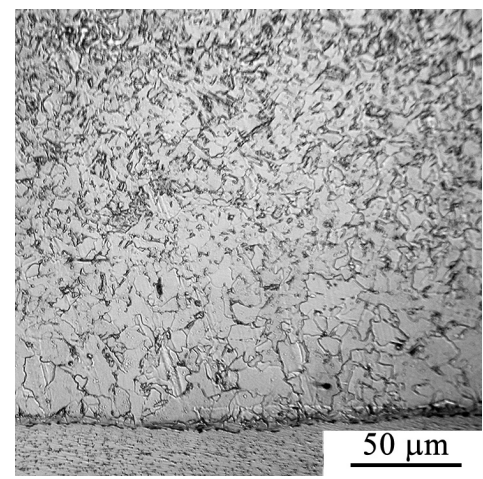

b

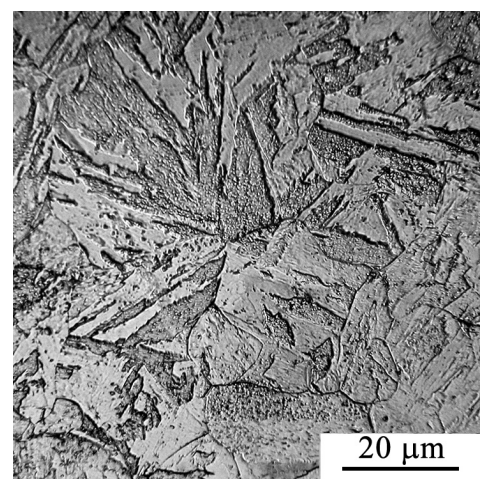

c

Fig. 4. The microstructure of the Fe-2Mn-1Si steel layers in the central part (a), at the interface (b) and the Fe-11Cr-9Ni-2Mo-1Ti steel layers in the central part (c) in the 7-layered hot-rolled composites after quenching at $920^{\circ} \mathrm{C}$. 
Additional heating of the quenched hot-rolled composites to $500^{\circ} \mathrm{C}$ with holding for 3 hours leads to softening of the Fe-2Mn-1Si steel layers, which results in the formation of a sorbitol-ferrite structure and coagulation of the carbide phase. This heat treatment regime is strengthening aging for $\mathrm{Fe}-11 \mathrm{Cr}-9 \mathrm{Ni}-2 \mathrm{Mo}-1 \mathrm{Ti}$ steel due to the precipitation of dispersed intermetallic particles contributed to the maximum strengthening of maraging steel [17].

The results of the impact test of explosively welded and hot-rolled composites (Table 1) showed that the impact strength characteristics are decreased with lowering test temperature from $+20^{\circ} \mathrm{C}$ to $-60^{\circ} \mathrm{C}$. However, the values of impact strength $\mathrm{KCV}$, energy of impact loading $A$ and energy of crack initiation $A_{i}$ match to a sufficiently high level at low test temperature $\left(-60^{\circ} \mathrm{C}\right)$.

As a rule, the complete destruction of all layers of welded and hot-rolled composites did not occur at all test temperatures (Fig. 5a,b). Therefore, the fixed values of impact strength $\mathrm{KCV}>1.10-2.54 \mathrm{MJ} / \mathrm{m}^{2}$ and energy of crack initiation $A_{i}>15.3-25.2 \mathrm{~J}$ include not only the energy of destruction of some layers, but also the energy expended in bending the unbroken composite layers. These features of the impact strength characteristics formation and the process of dynamic fracture of impact samples with a V-notch oriented across the interface (crack-arrester type) are attributed to two reasons. At first, the layered structure and, in particular, the appearances of delaminations at the dissimilar steel joints of the studied materials inhibit the development of the main crack and contribute to the crack initiation in each layer [18-19]. Such mechanical behavior of layered materials at dynamic loading gives a rise of impact strength characteristics due to the realization of the "delamination toughening" effect [20]. At second, the transition of the triaxial stress state in each layer into a biaxial (flat) layer, which is less dangerous for the fracture process, leads to the crack growth retardation [21].
The previous study of explosively welded 5-layered composites based on the same steels [10] demonstrated that the UFG structure of maraging steel layers provided a higher impact strength of these composites compared with the fine-grained (FG) structure of ones. A comparison of hot-rolled 7-layered composites (FG structure of Fe-11Cr-9Ni-2Mo-1Ti steel) with explosively welded composites (UFG structure of Fe-11Cr-9Ni-2Mo-1Ti steel) carried out during the study showed that the strength of joining in layered steel/steel composites has a greater effect on the impact strength characteristics than the presence of the UFG structure.

The more intense delamination of hot-rolled composites (Fig. $5 \mathrm{a}$ ) during the impact test as compared to explosively welded ones (Fig. $5 \mathrm{~b}$ ) is facilitated by the presence of oxide and carbide inclusions at the interface, which resulted in a decrease in the bonding strength of the layers and enhance the crack growth retardation effect. For this reason, the impact strength of hot-rolled composites was 2 times higher than that of explosively welded composites.

As can be seen from Fig. 5, "brittle jumps" appear on the impact loading diagrams of composites tested at a temperature of $-60^{\circ} \mathrm{C}[22]$, but at the same time, the extended sections of impact loading diagrams corresponding to the implementation of the viscous fracture mechanism are retained. It should be noted that the impact loading diagrams of hot-rolled composites compared to welded ones are more elongated on the $x$ axis ("deflection"), which is attributed to the presence of a longer delamination section of hot-rolled composites, which are characterized by a lower bonding strength of the layers.

Thus, the obtained results showed the possibility of effective use of layered steel/steel composites for the production of products and structural elements operating at low climatic temperatures.

Table 1. Impact strength characteristics of the 7-layered explosively welded and hot-rolled composites after heat treatment.

\begin{tabular}{|c|c|c|c|c|}
\hline $\begin{array}{c}\text { Fabrication technique } \\
\text { of composites }\end{array}$ & \multirow{2}{*}{$T,{ }^{\circ} \mathrm{C}$} & \multicolumn{3}{|c|}{ Impact strength characteristics } \\
\cline { 3 - 5 } & & Impact strength, KCV, MJ/m ${ }^{2}$ & Energy of impact loading, $A, \mathrm{~J}$ & Energy of crack initiation, $A_{i}, \mathrm{~J}$ \\
\hline \multirow{2}{*}{ Explosion welding } & +20 & $>1.32$ & $>53.6$ & 19.2 \\
\cline { 2 - 5 } & -60 & $>1.10$ & $>31.1$ & 14.8 \\
\hline \multirow{2}{*}{ Pack rolling } & +20 & $>2.54$ & $>188.3$ & 25.2 \\
\cline { 2 - 5 } & -60 & $>2.26$ & $>168.7$ & 24.7 \\
\hline
\end{tabular}

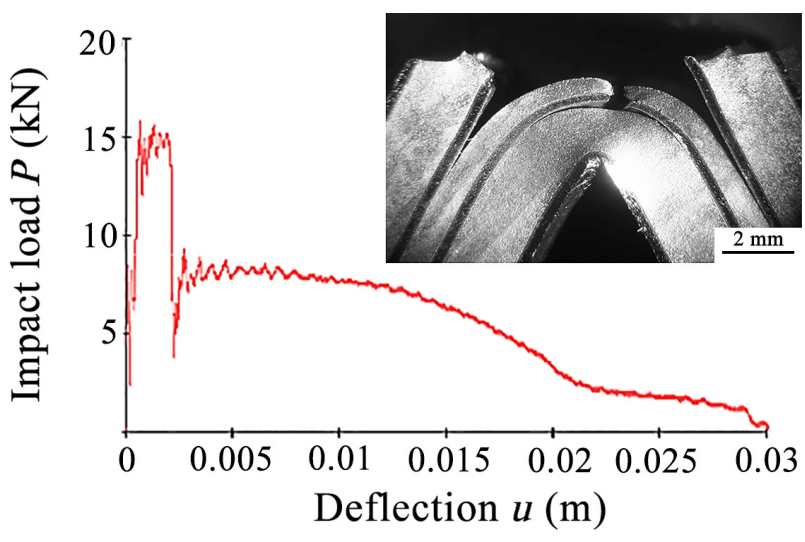

a

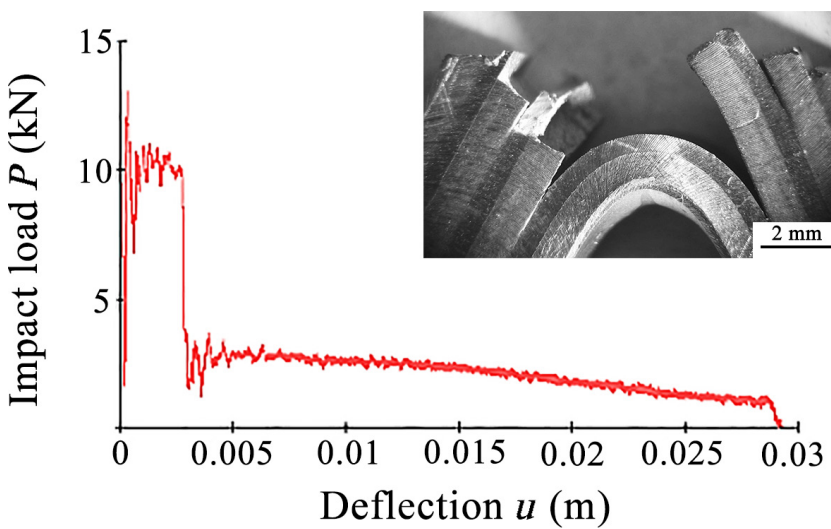

$\mathrm{b}$

Fig. 5. The lateral surface and impact loading diagrams of 7-layered hot-rolled (a) and explosively welded (b) composites at $-60^{\circ} \mathrm{C}$. 


\section{Conclusion}

1. The influence of the technology of fabrication of layered steel/steel composites on the interface structure is established. It clears up that explosively welded composites have an interface with a narrow diffusion zone $(5-7 \mu \mathrm{m})$ and do not contain welding macrodefects. On the other hand, 7-layered steel/steel hot-rolled composites have a wider diffusion zone $(\sim 25 \mu \mathrm{m})$ at the interface, which is characterized by the presence of pores and inclusions.

2. The dynamic recrystallization during explosion welding of composites leads to the formation of fragmented zone with a width of $\sim 10 \mu \mathrm{m}$ and a crystallite size of $0.5-1.0 \mu \mathrm{m}$ near the interface on the side of Fe-2Mn-1Si steel. As a result of the ascending diffusion of carbon from low carbon steel to maraging steel layers during hot pack rolling, the decarburized zone having a width of $\sim 50 \mu \mathrm{m}$ is formed near the interface on the side of the Fe-2Mn-1Si steel layer.

3. The high stability of the initial UFG structure, formed by the preliminary combined deformational process of maraging steel during subsequent explosion welding process, is stated. The final microstructure of the composite components consists of a ferrite (sorbitol)-perlite structure in the $\mathrm{Fe}-2 \mathrm{Mn}-1 \mathrm{Si}$ steel layers and a massive martensitic UFG structure with strengthening intermetallic particles in maraging steel layers.

4. The explosively welded and hot-rolled composites with crack-arrester geometry do not completely destruct at temperatures of +20 and $-60^{\circ} \mathrm{C}$ and have high values of impact strength characteristics, which is related to the effect of "delamination toughening" at the interface and transition of the triaxial stress state in each layer into a biaxial one.

5. Hot pack rolling allows to obtain 2 and 3.5-5.4 times higher values of impact strength and energy of impact loading respectively at temperatures of +20 and $-60^{\circ} \mathrm{C}$ that is associated with an increased crack growth retardation in hot-rolled composites by longer sections of delamination at the interface.

Acknowledgments. The authors are grateful to I.S. Kamancev for experimental assistance in hot rolling of composites and R.M. Galeev for thermal-deformation processing of sheet $\mathrm{Fe}-11 \mathrm{Cr}$-9Ni-2Mo-1Ti steel to create UFG structure. The research was by supported in part by the state assignment to the Institute of Engineering Science, UB RAS, no. №AAAA-A18-118020790147-4 and the project of UB RAS, no. 18-9-1-20 ("Arktica" program).

\section{References}

1. Yu. P. Trykov, L. M. Gurevich, V. G. Shmorgunov. Sloistyye kompozity na osnove alyuminiya i yego splavov. Moscow, Metallurgiya (2004) 230 p. (in Russian)

2. N. Chawla, K.N. Chawla. Metal matrix composites, 2nd ed. New York, Springer Science + Business Media (2013) 370 p. $\underline{\text { Crossref }}$
3. S. V. Smirnov, I. A. Veretennikova. DREAM. 4, 6 (2015). (in Russian) Crossref

4. D. Brigante. New Composite Materials: Selection, Design, and Application. Springer International Publishing (2014) $179 \mathrm{p}$.

5. S. V. Gladkovsky, S.V. Kuteneva, S.N. Sergeev. Mater. Charact. 154, 294 (2019). Crossref

6. I.A. Bataev, T.S. Ogneva, A.A. Bataev, V.I. Mali, M.A. Esikov, D.V. Lazurenko, Y. Guo, A.M. Jorge Junior. Mater. Des. 88, 1082 (2015). Crossref

7. L.A. Maltseva, D.S. Tyushlyaeva, T.V. Maltseva, M. V. Pastukhov, N.N. Lozhkin, D. V. Inyakin, L. A. Marshuk. Deformatsiya I Razrushenie Materialov. 4, 19 (2013). (in Russian)

8. V.I. Mali, A. A. Bataev, I.N. Maliutina, V.D. Kurguzov, I. A. Bataev, M.A. Esikov, V.S. Lozhkin. Int. J. Adv. Manuf. Technol. 93 (9-12), 4285 (2017). Crossref

9. V.S. Lozhkin. Obrabotka metallov: tekhnologiya, oborudovanie, instrumenty. 3, 110 (2013). (in Russian)

10. S. V. Gladkovsky, S.V. Kuteneva, I.S. Kamantsev, R. M. Galeev, D. A. Dvoynikov. DREAM. 6, 71 (2017). (in Russian) Crossref

11. V.I. Mali, I.A. Bataev, A.A. Bataev, D.V. Pavlyukova, E. A. Prikhodko, M. A. Esikov. Physical Mesomechanics. 14 (6), 117 (2011). (in Russian)

12. J.D. Embury, N.J. Petch, A.E. Wraith. Transaction of Metal Science. AIME. 239, 114 (1967).

13. Z. Dhib, N. Guermazi, M. Gaspérini, N. Haddar. Mater. Sci. Eng. A. 656, 130 (2016). Crossref

14. A. Khadadad Motarjemi, M. Koçak, V. Ventzke. Int. J. Pres. Ves. Pip. 79 (3), 181 (2002). Crossref

15. M.D. Perkas, V.M. Kardonskii. High-Strength Maraging Steels. Moscow, Metallurgiya (1970) 224 p. (in Russian)

16. S. V. Gladkovsky, A. I. Potapov, S. V. Lepikhin. DREAM. 4, 18 (2015). (in Russian) Crossref

17. J.W. Martin. Micromechanisms in ParticleHardened Alloys. Moscow, Metallurgiya (1983) 167 p. (in Russian)

18. S.V. Gladkovsky, S.V. Kuteneva, V.E. Veselova, E.A. Kokovikhin. Bulletin PNRPU. Mechanical engineering, materials science. 18 (3), 77 (2016). (in Russian) Crossref

19. A. A. Sarkeeva, A.A. Kruglov, E.M. Borodin, S. V. Gladkovsky, R. Ya. Lutfullin. Phys. Mesomech. 15 (5), 51 (2012). (in Russian)

20. K. Babinsky, S. Primig, W. Knabl et al. JOM. 68 (11), 2854 (2016). Crossref

21. P.G. Mikljaev, G.S. Neshpor, V.G. Kudrjashov. The kinetics of destruction. Moscow, Metallurgiya (1979) 279 p. (in Russian)

22. R. L. Botvina. Fracture. Kinetika, mekhanizmy, obshchiye zakonomernosti. Moscow, Nauka (2008) 334 p. (in Russian). 